\title{
Age-related modulation of plasmatic beta-Galactosidase activity in healthy subjects and in patients affected by T2DM
}

\author{
Liana Spazzafumo ${ }^{1, *}$, Emanuela Mensà ${ }^{2,}{ }^{,}$, Giulia Matacchione ${ }^{2, *}$, Tiziana Galeazzi $^{3}$, \\ Lucia Zampini ${ }^{3}$, Rina Recchioni ${ }^{4}$, Fiorella Marcheselli ${ }^{4}$, Francesco Prattichizzo ${ }^{5}$, \\ Roberto Testa6, Roberto Antonicelli7, Paolo Garagnani ${ }^{8,9}$, Massimo Boemi ${ }^{10}$, \\ Massimiliano Bonafè ${ }^{8}$, Anna Rita Bonfigli11, Antonio Domenico Procopio ${ }^{2,4}$ and \\ Fabiola Olivieri'2,4 \\ ${ }^{1}$ Center of Biostatics, INRCA-IRCCS National Institute, Ancona, Italy \\ 2 Department of Clinical and Molecular Sciences, DISCLIMO, Università Politecnica delle Marche, Ancona, Italy \\ ${ }^{3}$ Pediatric Division, Department of Clinical Sciences, Università Politecnica delle Marche, Ospedali Riuniti, Presidio Salesi, \\ Ancona, Italy \\ ${ }^{4}$ Center of Clinical Pathology and Innovative Therapy, INRCA-IRCCS National Institute, Ancona, Italy \\ ${ }^{5}$ Department of Cardiovascular and Metabolic Diseases, IRCCS Multimedica, Sesto San Giovanni, Italy \\ ${ }^{6}$ Clinical Laboratory and Molecular Diagnostics, INRCA-IRCCS National Institute, Ancona, Italy \\ 7 UTIC-Cardiology INRCA-IRCCS, National Institute, Ancona, Italy \\ ${ }^{8}$ Department of Experimental, Diagnostic and Specialty Medicine, Alma Mater Studiorum, University of Bologna, Bologna, \\ Italy \\ ${ }^{9}$ Clinical Chemistry, Department of Laboratory Medicine, Karolinska Institutet at Huddinge University Hospital, Stockholm, \\ Sweden \\ ${ }^{10}$ Diabetology Unit, INRCA-IRCCS, National Institute, Ancona, Italy \\ 11 Scientific Direction, INRCA-IRCCS, National Institute, Ancona, Italy \\ * The authors contributed equally to this work \\ Correspondence to: Anna Rita Bonfigli, email: a.bonfigli@inrca.it \\ Keywords: cellular senescence; beta galactosidase activity; type 2 diabetes; aging; inflammaging; Gerotarget \\ Received: August 02, $2017 \quad$ Accepted: October 04, $2017 \quad$ Published: October 16, 2017
}

Copyright: Spazzafumo et al. This is an open-access article distributed under the terms of the Creative Commons Attribution License 3.0 (CC BY 3.0), which permits unrestricted use, distribution, and reproduction in any medium, provided the original author and source are credited.

\section{ABSTRACT}

$\beta$-Galactosidase ( $\beta$-Gal) activity has been the most extensively utilized biomarker for the detection of cellular senescence. It can be measured also in plasma, and few recent evidence showed an altered plasmatic $\beta$-Gal activity in patients affected by some age-related diseases (ARDs). Since T2DM is one of the most common ARDs, we aimed to investigate if plasmatic $\beta$-Gal activity is modulated in T2DM patients and if "age" could affect such modulation. To gain mechanistic insights we paralleled this investigation with the evaluation of $\beta$-Gal activity in young and senescent endothelial cells (HUVECs) cultured in normo- and hyper-glycaemic environment.

A significant age-related increase of plasmatic $\beta$-Gal activity was observed in healthy subjects ( $n$. 230; 55-87 years), whereas the enzymatic activity was significantly reduced in T2DM patients ( $n$. 230; 55-96 years) compared to healthy subjects.

$\beta$-Gal activity detectable both in cells and in the culture medium was significantly increased in senescent cells compared to the younger ones, both under normoand hyper-glycaemic condition. However, the hyper-glycaemic condition was not associated with an increased $\beta$-Gal activity in milieu compared to normo-glycaemic condition.

Overall our data reinforce the notion that plasmatic $\beta$-Gal activity could be a systemic biomarker of aging, whereas T2DM patients are characterized by a different age-releated trend. 


\section{INTRODUCTION}

The human lysosomal enzyme $\beta$-D-galactosidase $(\beta-\mathrm{Gal})$ is an exoglycosidase that catalyzes the hydrolysis of terminal $\beta$-linked galactose residues in glycoproteins, glycolipids and proteoglycans [1]. A deficiency of lysosomal acid $\beta$-Gal activity detectable in blood cells, i.e. leukocytes, and biological fluids, i.e. plasma, is currently a diagnostic biomarker for some rare inherited lysosomal storage diseases, such as GM1-gangliosidosis and Morquio $\mathrm{B}$ disease [2]. Increasing evidence support the view that the integrity of the autophagosomal-lysosomal network is critical in the progression of aging [3]. This hypothesis is reinforced by the evidence that lysosomal dysfunctions are associated with the onset and progression of many age-related diseases (ARDs), including Parkinson's and Alzheimer's disease (AD) $[4,5]$ and type 2 diabetes (T2DM) $[6,7]$. Altered transcriptional and translational levels of several lysosomal glycohydrolases and proteases, including $\beta$-Gal, was observed in skin fibroblasts, leukocytes and post-synaptic vesicles of patients affected by $\mathrm{AD}[7-10]$. Increased $\beta$-Gal activity in leukocytes was observed also in patients affected by Down's syndrome (DS), patients with an increased risk of develop many age-related chronic diseases $[9,11]$. Although in the past little attention was paid to glycohydrolases present in cellular compartments different from lysosomes, growing evidence suggested the presence of active lysosomal enzymes in extra-lysosomal compartments, such as the plasma membrane [12] and the extracellular environment [13]. Autophagolysosomes and their content instead of being fully processed by degradation can be extruded from cells through unconventional secretion mechanisms, including the so called "secretory autophagy" $[14,15]$. The link between $\beta$-Gal and aging is reinforced by the identification of a $\beta$-Gal activity in senescent cells, which has been named senescence-associated (SA)- $\beta$-Gal [16]. The increased SA- $\beta$-Gal activity observed in senescent cells seems due, at least partly, to the increased expression of the lysosomal $\beta$-Gal protein [17]. SA- $\beta$-Gal activity has been the most extensively utilized biomarker for the detection of cellular senescence both in vitro and ex vivo [18-22]. However, the remarkable asynchrony and heterogeneity of cellular senescence remain a challenge for investigating the relationship between the number of senescent cells, the rate of aging, and the risk of ARDs. The research of circulating biomarkers to measure the "systemic senescence status" is a cutting-edge problem. Plasmatic $\beta$-Gal activity can be measured, and some studies showed a differential plasmatic $\beta$-Gal activity in patients affected by AD and T2DM [7], as well as in many types of cancers $[23,24]$. It was therefore hypothesized that plasmatic $\beta$-Gal activity might be a manifestation of "systemic senescence status" in the course of ARDs [25].

A significant shift in serum $\mathrm{N}$-glycan profile was observed during ageing. The logarithm of the ratio between the agalactosylated glycan (NGA2F) and the galactosylated glycan (NA2F) showed a strong correlation with age and therefore it was named "GlycoAgeTest" [26]. Almost all secreted proteins are post-translationally modified with the covalent attachment of $\mathrm{N}$-glycans, and the $\beta$-Gal and others exoglycosidases are involved in the remodelling of N-glycan structures, including NGA2F and NA2F $[26,27]$. We previously observed specific $\mathrm{N}$-glycan profiles in T2DM patients [28].

Since T2DM is one of the most common agerelated diseases and no data are currently available on plasmatic modulation of $\beta$-Gal activity during aging and no studies have already evaluated the association between GlycoAgeTest and plasmatic $\beta$-Gal activity, we aimed to investigate these associations. To gain mechanistic insights we aimed to parallel the investigation on plasma samples with the evaluation of $\beta$-Gal activity both inside and outside young and senescent endothelial cells (HUVECs) cultured in normo-glycaemic and hyper-glycaemic environment, the latter ones mimicking the main diabetes pathological feature.

\section{RESULTS}

\section{Age-related trend of plasmatic $\beta$-Gal activity in healthy subjects and in T2DM patients}

The anthropometric and biochemical parameters of 230 healthy subjects, defined as control subjects (CTR) and 230 patients affected by T2DM (defined as T2DM) were reported in Table 1A and 1B, respectively. Since we aimed to investigate the age-related correlations of the selected parameters we grouped the subjects in three different age-classes such as: first group: $\geq 55$ and $<65$, second group: $\geq 65$ and $<75$ years and third group: $\geq 75$ years. These cut-offs are appropriate for considering a subject to be elderly, as reported in previous studies [29, 30].

The mean age of each group of subjects was about 60,70 and 80 respectively.

Significant increased values of plasmatic $\beta-G a l$ activity were observed in elderly CTR compared with younger ones (Table 1A).

Significant increase of C-reactive protein (CRP) mean value was observed in groups of 70 and 80 years compared to that of 60 years (Table 1A), whereas GlycoAge Test values decreased significantly among the three groups (Table 1A).

Significant age-related trends were confirmed by correlation analysis for plasmatic $\beta$-Gal activity (Pearson's correlation 0.24, $\mathrm{p}<0.01$ ), GlycoAge Test (Pearson's correlation $0.25, \mathrm{p}<0.01$ ) and CRP (Pearson's correlation $0.24, \mathrm{p}<0.01$ ), (Table 2).

In patients affected by T2DM no significant age- 
Table 1: Anthropometric and biochemical parameters. (A) Parameters of healthy subjects (n. 230).

\begin{tabular}{|c|c|c|c|c|}
\hline \multirow[t]{2}{*}{ Parameters } & \multicolumn{4}{|c|}{ Healthy subjects (n. 230) } \\
\hline & $\begin{array}{c}\geq 55 \text { and }<65 \text { years } \\
\text { (n. } 70 \text { ) }\end{array}$ & $\begin{array}{c}\geq 65 \text { and }<75 \text { years } \\
\text { (n. 115) }\end{array}$ & $\begin{array}{l}\geq 75 \text { years } \\
\text { (n. } 45 \text { ) }\end{array}$ & $\mathbf{P}$ \\
\hline BMI, $\mathrm{kg} / \mathrm{m}^{2}$ & $27.71 \pm 4.23$ & $27.26 \pm 4.33$ & $27.26 \pm 4.33$ & 0.959 \\
\hline $\mathrm{HDL}, \mathrm{mmol} / \mathrm{L}$ & $54.15 \pm 13.36$ & $54.91 \pm 16.78$ & $53.28 \pm 14.09$ & 0.021 \\
\hline $\mathrm{LDL}, \mathrm{mmol} / \mathrm{L}$ & $131.28 \pm 36.09$ & $128.04 \pm 31.77$ & $128.08 \pm 28.88$ & 0.868 \\
\hline $\mathrm{TC}, \mathrm{mmol} / \mathrm{L}$ & $220.35 \pm 37.87$ & $223.25 \pm 38.10$ & $214.99 \pm 39.02$ & 0.605 \\
\hline $\mathrm{FG}, \mathrm{mg} / \mathrm{dl}$ & $98.91 \pm 9.6$ & $93.60 \pm 10.51 \#$ & $94.80 \pm 10.91$ & 0.071 \\
\hline $\mathrm{HbAlc}$ & $5.78 \pm 0.38$ & $5.69 \pm 0.35$ & $5.74 \pm 0.45$ & 0.677 \\
\hline WC, & $6.37 \pm 1.52$ & $6.04 \pm 1.44$ & $5.88 \pm 1.41$ & 0.321 \\
\hline CRP & $2.43 \pm 3.21$ & $5.54 \pm 7.88 \#$ & $5.59 \pm 10.77 \#$ & 0.001 \\
\hline Creatinine & $0.86 \pm 0.19$ & $0.83 \pm 0.20$ & $0.86 \pm 0.24$ & 0.775 \\
\hline GlycoAgeTest & $-0.28 \pm 0.13$ & $-0.22 \pm 0.13 \#$ & $-0.18 \pm 0.13 \# *$ & $<0.001$ \\
\hline $\begin{array}{l}\text { Plasmatic } \beta \text {-Gal } \\
\text { activity } \\
(\mathrm{nM} / \mathrm{ml} / \mathrm{hr})\end{array}$ & $5.17 \pm 2.60$ & $5.49 \pm 3.68$ & $6.95 \pm 3.08^{*}$ & 0.016 \\
\hline
\end{tabular}

${ }^{*} \mathrm{p}<0.05$, comparison with $\geq 55$ and $<65$ years; $* \mathrm{p}<0.05$, comparison with $\geq 65$ and $<75$ years. P from ANOVA. Significant values were reported in bold. $\mathrm{TC}=$ total cholesterol; $\mathrm{FG}=$ fasting glucose; $\mathrm{Hb} 1 \mathrm{c}=$ Glycated haemoglobin; $\mathrm{WC}=$ white cells; $\mathrm{CRP}=\mathrm{C}$ Reactive Protein; GlycoAge Test $=\mathrm{Log}(\mathrm{CC} 1 / \mathrm{CC} 6)$.

related trend were observed for any analysed variables including $\beta$-Gal activity (Pearson's correlation: -0.12 , $\mathrm{p}=0.07$ ).

However, GlycoAge Test value was significantly reduced in groups of older patients (Table 1B) and a significant increase of creatinine mean value was observed in the group of the oldest T2DM patients (Table 1B).

When age-related trend of $\beta$-Gal activity was compared between healthy subjects and T2DM patients a significant difference was unravelled (ANOVA, $\mathrm{F}=4.916$, $\mathrm{p}=0.027$ ). Marginal means of $\beta-\mathrm{Gal}$ activity in healthy subjects and T2DM patients groups were shown in green and red respectively in Figure 1.

We then analysed the correlation between $\beta$-Gal and the others variables significantly related to age. No significant correlations were observed between plasmatic 
Table 1: Anthropometric and biochemical parameters. (B) Parameters of T2DM patients (n.230).

\begin{tabular}{|c|c|c|c|c|}
\hline Parameters & & T2DM (n. & & \\
\hline & $\begin{array}{c}\geq 55 \text { and }<65 \text { years } \\
\text { (n. 112) }\end{array}$ & $\begin{array}{c}\geq 65 \text { and }<75 \text { years } \\
\text { (n. 88) }\end{array}$ & $\begin{array}{c}\geq 75 \text { years } \\
\quad \text { (n. } 30)\end{array}$ & $\mathbf{P}$ \\
\hline BMI, $\mathrm{kg} / \mathrm{m}^{2}$ & $29.88 \pm 3.78$ & $28.97 \pm 4.06$ & $26.77 \pm 2.84$ & 0.249 \\
\hline $\mathrm{LDL}, \mathrm{mmol} / \mathrm{L}$ & $122.45 \pm 32.76$ & $121.34 \pm 31.22$ & $111.34 \pm 30.21$ & 0.581 \\
\hline $\mathrm{HDL}, \mathrm{mmol} / \mathrm{L}$ & $52.18 \pm 16.51$ & $54.08 \pm 15.31$ & $56.66 \pm 19.22$ & 0.516 \\
\hline $\mathrm{TC}, \mathrm{mmol} / \mathrm{L}$ & $211.66 \pm 39.66$ & $209.78 \pm 37.92$ & $212.76 \pm 36.88$ & 0.923 \\
\hline $\mathrm{FG}, \mathrm{mg} / \mathrm{dl}$ & $175.77 \pm 53.42$ & $164.65 \pm 47.22$ & $168.88 \pm 53.76$ & 0.631 \\
\hline $\mathrm{HbAlc}$ & $7.65 \pm 1.34$ & $7.34 \pm 1.08$ & $7.48 \pm 1.23$ & 0.355 \\
\hline WC & $6.82 \pm 1.78$ & $6.54 \pm 1.37$ & $6.21 \pm 1.17$ & 0.490 \\
\hline CRP & $4.66 \pm 6.33$ & $3.45 \pm 4.22$ & $3.88 \pm 2.75$ & 0.710 \\
\hline Creatinine & $0.86 \pm 0.27$ & $0.93 \pm 0.36$ & $1.21 \pm 0.55^{*}$ & 0.007 \\
\hline GlycoAgeTest & $-0.28 \pm 0.15$ & $-0.22 \pm 0.15 \#$ & $-0.23 \pm 0.15 \#$ & 0.146 \\
\hline $\begin{array}{l}\text { Plasmatic } \beta \text {-Gal } \\
\text { activity } \\
(\mathrm{nM} / \mathrm{ml} / \mathrm{hr})\end{array}$ & $4.79 \pm 3.88$ & $3.88 \pm 3.38$ & $4.46 \pm 3.07$ & 0.157 \\
\hline
\end{tabular}

${ }^{\#} \mathrm{p}<0.05$, comparison with $\geq 55$ and $<65$ years; $* \mathrm{p}<0.05$, comparison with $\geq 65$ and $<75$ years. P from ANOVA. Significant values were reported in bold. $\mathrm{TC}=$ total cholesterol; $\mathrm{FG}=$ fasting glucose; $\mathrm{Hb} A 1 \mathrm{c}=$ Glycated haemoglobin; $\mathrm{WC}=$ white cells; $\mathrm{CRP}=\mathrm{C}$ Reactive Protein; GlycoAge Test=Log (CC1/CC6).

$\beta$-Gal activity and GlycoAge Test in healthy subjects (data not shown). Therefore, to unravel the relative contribution of GlycoAge Test and $\beta$-Gal as age-related variables of healthy status, we performed a sequential linear regression analysis, including age as dependent variables and GlycoAge Test, $\beta$-Gal, CRP, HDL, and fasting glucose (FG) as independent variables. In the first step of regression analysis a significant correlation between $\beta$-Gal and age was confirmed (beta coefficient $=$
$0.23, \mathrm{p}<0.0011$ ), as well as between GlycoAge Test and age (beta coefficient $=0.24, \mathrm{p}<0.001$ ). In the second step, all the parameters significantly related with age, including FG, were included as independent variables, confirming the significant correlation between $\beta$-Gal and age (beta coefficient $=0.21, \mathrm{p}=0.001$ for $\beta$-Gal and beta coefficient $=$ $0.20, \mathrm{p}<0.002$ for GlycoAge Test).

The sequential multiple regression revealed that, at step one, GlycoAge Test and $\beta$-Gal contribute significantly 
Table 2: Correlation between plasmatic parameters and age of healthy subjects. Healthy subjects, $n=230$

\begin{tabular}{|l|c|c|}
\hline & \multicolumn{2}{|c|}{ healthy subjects (n. 230) } \\
\hline & Pearson's correlation & p \\
\hline FG, mg/dl & -0.12 & 0.07 \\
\hline CRP & $\mathbf{0 . 2 4}$ & $<\mathbf{0 . 0 1}$ \\
\hline GlycoAgeTest & $\mathbf{0 . 2 5}$ & $<\mathbf{0 . 0 1}$ \\
\hline$\beta-$ Gal & $\mathbf{0 . 2 4}$ & $<\mathbf{0 . 0 1}$ \\
\hline
\end{tabular}

to the regression model $(\mathrm{F}$ test $=13.85, \mathrm{p}<0.001)$ and account for about $11 \%$ of the variation in Age. The addition of the others parameters, such as HDL, CRP and FG to the regression model, explains an additional $4.1 \%$ of the variation in Age (Figure 2, R squared $=0.15$ ).

Standardized predicted $\beta-$ Gal activity values for healthy subjects were shown in Figure 2.

\section{Comparison of plasmatic $\beta$-Gal activity between T2DM patients and age-matched CTR}

Plasmatic $\beta$-Gal activity was significantly decreased in T2DM patients aged more than 65 years compared to age-matched healthy subjects (Figure 3). Linear regression analysis did not identified parameters with significant ageassociation in T2DM patients (data not shown).

Plasmatic $\beta$-Gal activity was not significantly different among the three age-groups of T2DM patients according to the presence of at least one complication (data not shown). When the three age-groups of T2DM patients were grouped according to $\mathrm{HbA} 1 \mathrm{c}$ cut-off level (7\%), plasmatic $\beta$-Gal activity was not significantly different (data not shown). Finally, when T2DM patients were grouped according to metformin or sulfonylurea treatments, plasmatic $\beta$-Gal activity was not significantly different among the three age-groups (data not shown).

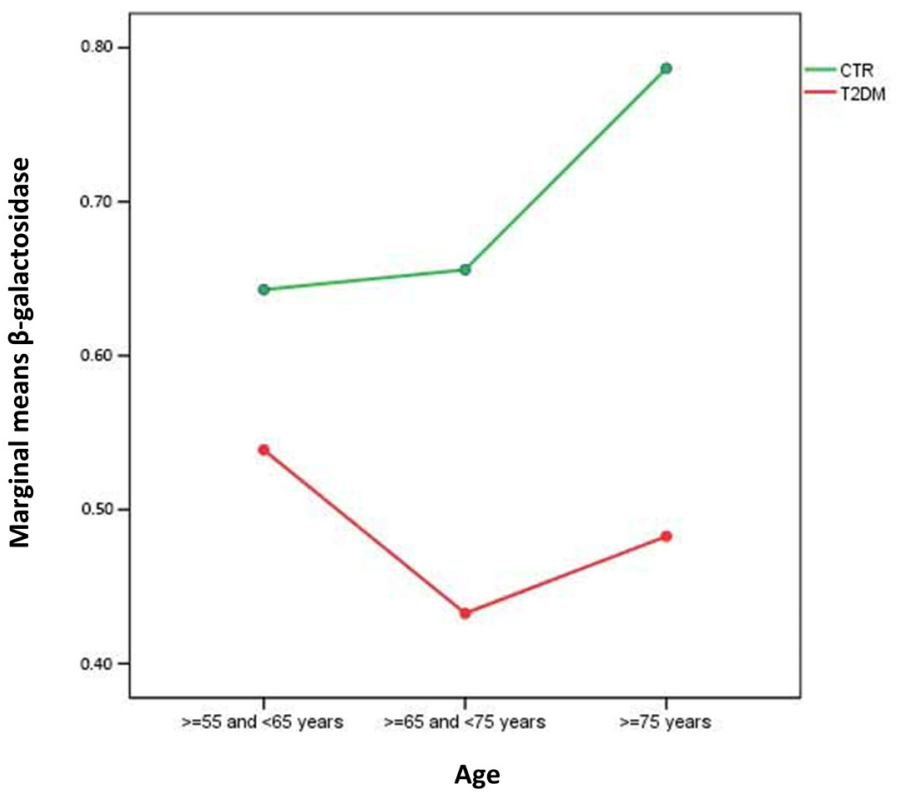

Figure 1: Marginal means of $\boldsymbol{\beta}-$ Gal activity in healthy subjects and T2DM patients groups. Healthy subjects, green line, $\mathrm{n}=230$; T2DM patients, red line, $\mathrm{n}=230$. First group: $\geq 55$ and $<65$, second group $: \geq 65$ and $<75$ years and third group $: \geq 75$ years. 


\section{$\beta$-Gal activity in young and senescent endothelial cells}

$\beta$-Gal activity was evaluated in young and senescent HUVECs cultured both in normo- and hyper-glycaemic milieu. $\beta$-Gal activity was evaluated in cells and in supernatants, in order to obtain data on the enzyme release. A significant 4.8 -fold increased activity was observed in senescent cells compared to the younger ones in normo-glycaemic condition whereas in hyper-glycaemic condition $\beta$-Gal activity increased 11 -fold in senescent cells vs. younger cells (Figure 4A). In senescent HUVEC cultured in hyper-glycaemic medium $\beta$-Gal activity was also significantly increased in comparison with senescent cells cultured in normo-glycaemic condition (Figure 4A).

$\beta$-Gal activity detectable in the culture medium was significantly increased in senescent cells compared to the younger ones, both under normo- and hyper-glycaemic milieu (Figure 4B). However, the hyper-glycaemic

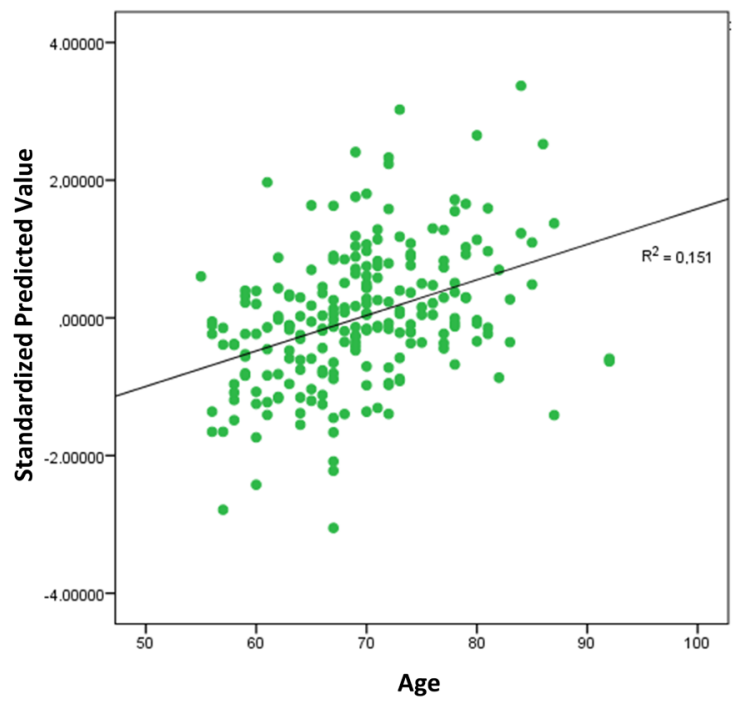

\begin{tabular}{|c|c|c|c|c|c|c|}
\hline & & \multicolumn{2}{|c|}{$\begin{array}{c}\text { Unstandardized } \\
\text { Coefficients }\end{array}$} & \multirow{2}{*}{$\begin{array}{c}\text { Standardized } \\
\text { Coefficients } \\
\text { Beta } \\
\end{array}$} & \multirow[b]{2}{*}{$\mathrm{t}$} & \multirow[b]{2}{*}{ Sig. } \\
\hline & & $\mathrm{B}$ & Error std & & & \\
\hline \multirow[t]{2}{*}{1 step } & GlycoAge Test & 12.97 & 3.46 & 0.24 & 3.75 & 0.000 \\
\hline & $\beta$-Gal & 0.50 & 0.14 & 0.23 & 3.54 & 0.000 \\
\hline \multirow[t]{5}{*}{2 step } & GlycoAge Test & 11.06 & 3.48 & 0.20 & 3.18 & 0.002 \\
\hline & $\beta$-Gal & 0.48 & 0.14 & 0.21 & 3.33 & 0.001 \\
\hline & CRP & 2.80 & 0.92 & 0.20 & 3.04 & 0.003 \\
\hline & HDL & 0.00 & 0.03 & -0.01 & -0.11 & 0.913 \\
\hline & FG & -0.04 & 0.05 & 0.05 & -0.84 & 0.403 \\
\hline
\end{tabular}

Figure 2: Standardized predicted values of $\boldsymbol{\beta}$-Gal activity in plasma from healthy subjects. Plasma from healthy subjects, $\mathrm{n}=230$.

\section{Plasmatic $\beta$-galactosidase activity}

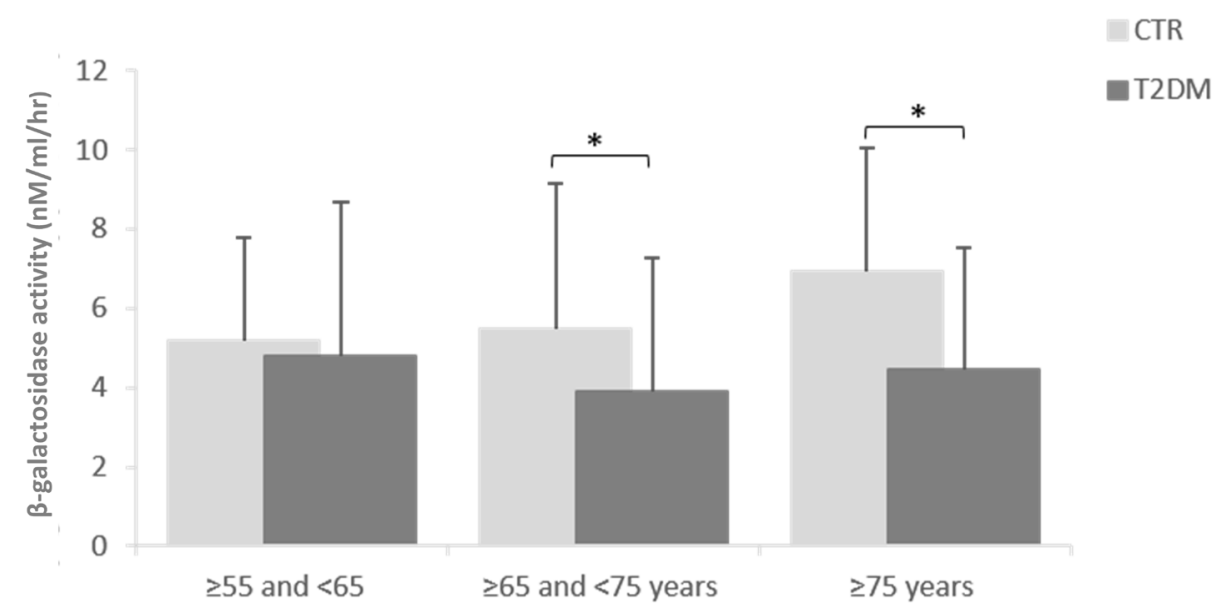

Figure 3: Plasmatic $\beta$-Gal activity in T2DM patients compared to age-matched healthy subjects. Healthy subjects, $n=230$; T2DM patients, $\mathrm{n}=230$. First group: $\geq 55$ and $<65$, second group : $\geq 65$ and $<75$ years and third group : $\geq 75$ years. Plasmatic $\beta$-Gal activity was reported as $\mathrm{nM} / \mathrm{ml} / \mathrm{hr}$. 
condition is not associated with an increased $\beta$-Gal activity in milieu compared to normo-glycaemic condition (Figure 4B).

\section{DISCUSSION}

This is the first report demonstrating a significant age-related increase of plasmatic $\beta$-Gal activity in healthy subjects. $\beta$-Gal activity is the most widely used biomarker for the identification of senescent cells and our results can be considered a "proof of principle" that plasmatic $\beta$-Gal activity could be a non-invasive surrogate biomarker able to track senescent cells burden at systemic level. The relevance of our result is related to the evidence that the delaying of senescent cell accumulation or the reduction of senescent cell burden is associated with delay, prevention, or alleviation of multiple senescence-associated conditions and ARDs [31]. Faithful meters are needed to estimate the effects of intervention based on recently discovered molecules able to modulate the senescence process.

When we measured $\beta$-Gal activity in plasma of T2DM patients of different age, we observed that the enzymatic activity was significantly reduced in T2DM patients compared to CTR, confirming a previous result [7]. Considering T2DM patients as subjects with an accelerated systemic senescence, this is a counterintuitive result [32-34]. Different phenomena could explain the reduced plasmatic $\beta$-Gal activity in T2DM patients: 1diabetic state could worsen lysosomal dysfunction [35]; 2- chronic hyperglycaemia/diabetic status could induce a number of imbalances in enzymes involved in hexoses metabolism, including galactosidases [36]; 3- an increased release of proteins derived from lysosomes and vascular epithelium into the urine may result from hyperglycemiaassociated inflammation in the kidney vasculature, as recently suggested in patients affected by T1DM [37]; 4hyperglycaemia could modulate the secretory abilities of cells. To verify this latter hypothesis, we measured $\beta$-Gal activity in young and senescent HUVECs and in their supernatants. We observed a significant increased $\beta-\mathrm{Gal}$ activity in senescent cells compared to younger ones, confirming our previous results on SA- $\beta$-Gal in HUVECs [38].

In normo-glycaemic condition $\beta$-Gal activity measured in in vitro vs. ex vivo models showed concordant results, suggesting that there is a significant increasing age- and senescence-related trend. In hyper-glycaemic condition $\beta-$ Gal activity measured in in vitro vs. ex vivo models showed discordant results, since the decreasing trend observed in ex vivo was not confirmed in in vitro

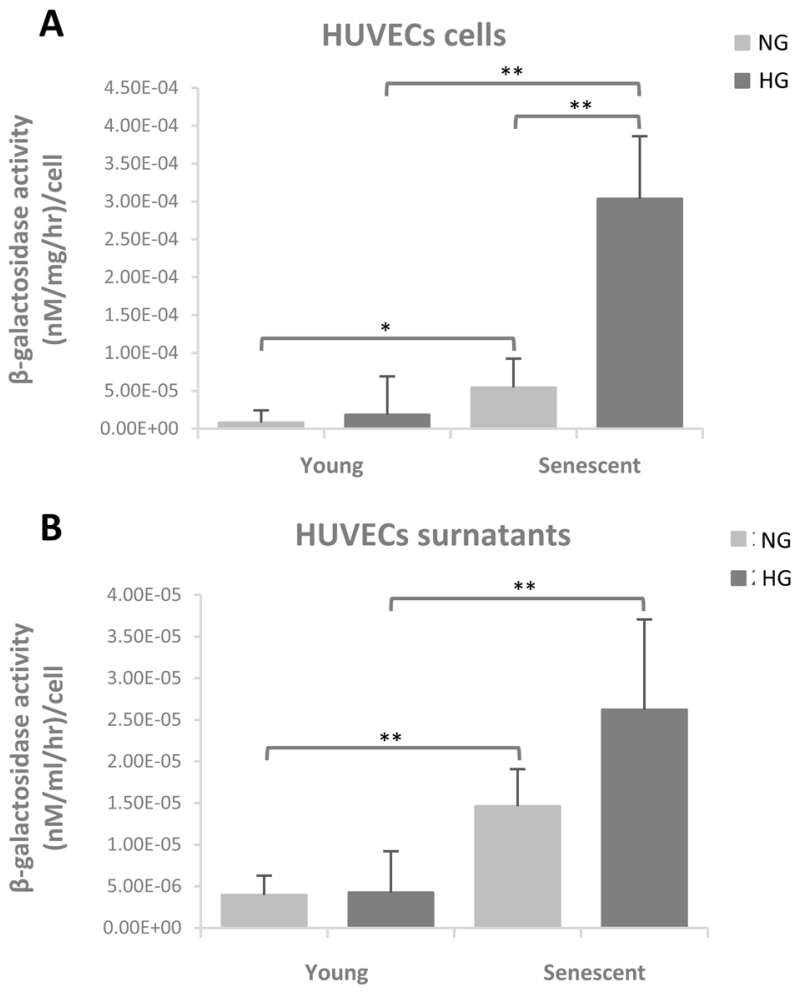

Figure 4: $\beta$-Gal activity evaluated in young and senescent HUVECs cultured both in normoglycaemic and hyperglycaemic milieu. (A) $\beta$-Galactosidase activity in cells reported as (nM/mg/hr)/cell (B) $\beta$-Galactosidase activity in supernatants reported as $(\mathrm{nM} / \mathrm{ml} / \mathrm{hr}) /$ cell. Data are presented as mean and standard deviation (SD) of three independent experiments. Hyperglycaemic milieu: glucose $25 \mathrm{mM}$. 
experiments on endothelial cells. These apparently conflicting results could be explained considering that tissues different from endothelium could contribute to circulating $\beta$-Gal activity and/or that pharmacological therapies could affect plasmatic $\beta$-Gal activity. When T2DM patients were grouped according to metformin or sulfonylurea treatments, plasmatic $\beta$-Gal activity was not significantly different among the three age-groups, suggesting that it was not affected by hypoglycemic agents. However, we cannot exclude that pharmacological therapies different from metformin and sulfonylurea (i.e. statins or beta-blockers) could affect plasmatic $\beta$-Gal activity. Further studies including more detailed information on pharmacological therapy could clarify this issue.

Moreover, since T2DM patients escape from the age-related trend of plasmatic $\beta-$ Gal activity observed in healthy subjects, probably due to their consistent metabolic imbalances, further studies including patients affected by different ARDs are mandatory.

Notably, $\beta$-Gal and others exoglycosidase are involved in the remodelling of $\mathrm{N}$-glycan structures [26, 27, $39,40]$. The GlycoAge Test, showed a strong correlation with chronological age $[26,41,42]$. Notably, the structures of the glycan linked to the plasmatic proteins (i.e. IgGs), modulate the pro- or anti-inflammatory activities of the proteins, because the glycoforms lacking terminal galactose are particularly proinflammatory, whereas the bigalactosylated glycans are anti-inflammatory [43]. Therefore, the progressive age-associated glycan changing is consistent with a shift toward a pro-inflammatory agalactosylated glycotype, that could contribute to fuel inflammaging, the chronic, systemic, low levels of inflammation involved in the development of the most common ARDs [44, 45].

A significant age-related increase of plasmatic $\beta 4$-galactosyltransferase activity, involved in the transformation of NGA2F in NA2F glycan was recently reported [44], whereas the age-related trend of plasmatic $\beta$-Gal activity, involved in the transformation of NA2F in $\mathrm{NGA} 2 \mathrm{~F}$, has never been investigated. We hypothesized a correlation between plasmatic $\beta$-Gal activity and agalactosylated plasmatic glycans levels.

However, we did not observe a significant correlation between the two parameters. Our results are in line with data obtained by Catera and colleagues [44], showing that glycosylation of plasmatic proteins is not correlated with the activity of the plasmatic glycosyltransferases.

Notably, $\beta$-Gal activity was detected at $\mathrm{pH} 4$, but the activity of plasmatic $\beta$-Gal at physiological $\mathrm{pH}$ could be lower than that measured at $\mathrm{pH} 4$. We cannot exclude that plasma $\beta$-Gal could be contained inside exosomes or others microvesicles and that the internal $\mathrm{pH}$ of these organelles could be different from that of plasma.

Overall our data reinforce the notion that plasmatic
$\beta$-Gal activity detectable with a simple biochemical assay could be a systemic biomarker of aging, and should be analysed in association with the GlycoAgeTest. However, the molecular mechanisms involved in the shift toward a pro-inflammatory agalactosylated glycotype during aging, as well as the mechanisms involved in the release of lysosomal enzymes in plasma and their functions deserve further investigations.

\section{MATERIALS AND METHODS}

\section{Subjects}

This study involved subgroups of a cohort of 501 T2DM patients and 400 healthy subjects enrolled in the framework of an Italian national study to identify biological parameters associated with T2DM [46]. All the information collected and the inclusion criteria were as described in Testa [46].

Since T2DM is a well characterized age-related disease we selected only subjects with age $\geq 55$ years. Among the 490 T2DM patients and 300 healthy subjects older than 55 years we selected for the present study $230 \mathrm{~T} 2 \mathrm{DM}$ patients and 230 healthy subjects taking into account the availability of plasma samples. The age ranges were 55-87 years and 55-96 years for T2DM and healthy subjects respectively.

Of the $230 \mathrm{~T} 2 \mathrm{DM}$ patients, 134 have at least one complication, such as retinopathy (n. 93), major adverse cardiac events (MACE) (n. 49), neuropathy (n. 41), nephropathy (n. 28), lower limb arteriopathy (n. 7) and chronic renal failure (n. 9). Each patient could have more than one complications.

\section{Cellular models}

HUVECs were purchased from Clonetics Corporation (Lonza, Basel, Switzerland) and cultured in EGM-2 endothelial growth medium (Lonza). Briefly, fresh cells were seeded at a density of 2,500 cells $/ \mathrm{cm}^{2}$ in T 75 flasks, the medium was changed every $48 \mathrm{~h}$. Cultures reached confluence after 6-7 days, as assessed by light microscopic examination, and were passaged at weekly intervals. After trypsinization and before replating, harvested cells were counted using a haemocytometer. Replicative senescence was studied by culturing cells until the proliferative arrest, as described previously [47]. Viable cells were counted at each passage by trypan blue staining; population doublings (PDs) were determined as current PDs $=$ last PDs $+\log 2$ (collected cell number / seeded cell number); cumulative population doubling (CPD) was calculated as the sum of all PD changes [38].

Cells were divided into young $(\mathrm{CPD}=20 \pm 2)$ and senescent $(\mathrm{CPD}=46 \pm 2)$. The characterization of 
senescence status was performed as described in Olivieri [38].

A hyperglycaemia-like environment was obtained by culturing young and senescent HUVECs in high glucose (25 mM) medium (HG) for 7 days.

\section{Laboratory assays}

Glycaemia, glycated haemoglobin (HbA1c), total cholesterol, HDL, CRP and white blood cell (WC), were determined by standard automated procedures.

\section{Quantitative assay of $\beta$-Gal activity using endothelial cells and plasma samples}

Endothelial cells or plasma $\beta$-Galactosidase activity was measured performing a fluorometric assay using $1 \mathrm{mM}$ 4-Methyl-umbelliferyl- $\beta$-D-galactopyranoside in citratephosphate buffer, $\mathrm{pH} 4.0$ as substrate.

Endothelial cells pellet was re-suspended in a suitable amount of water and sonicated 3 times for 15 " in ice-bath to obtain homogenous cells suspension. A quantitative estimation of total protein concentration was made using a colorimetric assay (Bio-Rad Protein Assay,) reading the optical density (OD) at $595 \mathrm{~nm}$ [48].

$50 \mu \mathrm{L}$ of plasma samples and a variable volume of cells suspension $(\mu \mathrm{L})$ containing 20-30 $\mu \mathrm{g}$ of proteins, were incubated with $200 \mu \mathrm{L}$ and $300 \mu \mathrm{L}$ of the substrate solution, respectively. After 1 hour at $37^{\circ} \mathrm{C}$, the reaction was stopped with $2.5 \mathrm{~mL}$ of glycine-carbonate buffer. The fluorescence of the liberated 4-Methylumbelliferone was measured on RF-1501 spectrofluorophotometer (Shimadzu) at excitation wavelength $=360 \mathrm{~nm}$ and at emission wavelength $=446 \mathrm{~nm}$.

Enzymatic activity was expressed in $\mathrm{nM} / \mathrm{mg} / \mathrm{hr}$ for endothelial cells and $\mathrm{nM} / \mathrm{ml} / \mathrm{hr}$ for plasma samples respectively [49].

\section{The GlycoAge Test}

The N-linked glycans peaks 1 and 6 were previously analyzed [28], using DSA-FACE technology, as previously described [26]. Peak 1 is the NGA2F, whereas peak 6 is its bigalactosylated counterpart NA2F. The Log of the ratio of the relative abundance of peaks 1 and 6 was defined "GlycoAge Test" [26].

\section{Statistical analysis}

Comparisons among groups were conducted with the analysis of variance (ANOVA) and covariance (ANCOVA) as appropriate.

Correlations between parameters were calculated using Pearson's correlation coefficient or partial correlation coefficient (r) controlled for age.

Sequential regression was employed to determine if additional parameters could improve the prediction of age beyond that afforded by differences in GlycoAge Test and $\beta$-Gal in healthy subjects. A two steps multiple regression was conducted with Age as the dependent variable. GlycoAge Test and $\beta$-Gal were included in the analysis at step one, whereas the others parameters were entered at stage two of regression.

Data analysis was carried out with the SPSS/Win program version 22 (SPSS, Chicago, IL). Statistical significance was defined as a two-tailed $\mathrm{p}$ value $<0.05$.

\section{Authors contributions}

FO, ARB, EM, GM and LS planned the experiments. RR, FM, EM and GM performed HUVECs experiments. TG and LZ measured beta galactosidase activity. RA, RT, $\mathrm{MB}$ and $\mathrm{ARB}$ were responsible for clinical data on T2DM patient and control healthy subjects. LS was responsible for statistical analysis. PG, FP, MB and ADP revised the manuscript critically. All authors read and approved the final manuscript.

\section{CONFLICTS OF INTEREST}

None of the authors has competing interests.

\section{FUNDING}

This work was supported by grants from: -Università Politecnica delle Marche, Italy, RSA to ADP and FO; -Università Politecnica delle Marche, Italy, MIRAGE project.

We thank the Umberto Veronesi Foundation for the support to the study.

\section{REFERENCES}

1. Ohto U, Usui K, Ochi T, Yuki K, Satow Y, Shimizu T. Crystal structure of human $\beta$-galactosidase: structural basis of $\mathrm{Gm} 1$ gangliosidosis and morquio $\mathrm{B}$ diseases. J Biol Chem. 2012; 287:1801-12.

2. Caciotti A, Garman SC, Rivera-Colón Y, Procopio E, Catarzi S, Ferri L, Guido C, Martelli P, Parini R, Antuzzi D, Battini R, Sibilio M, Simonati A, et al. GM1 gangliosidosis and Morquio B disease: an update on genetic alterations and clinical findings. Biochim Biophys Acta. 2011; 1812:78290.

3. Rajawat YS, Hilioti Z, Bossis I. Aging: central role for autophagy and the lysosomal degradative system. Ageing Res Rev. 2009; 8:199-213.

4. Carmona-Gutierrez D, Hughes AL, Madeo F, Ruckenstuhl C. The crucial impact of lysosomes in aging and longevity. 
Ageing Res Rev. 2016; 32:2-12.

5. Nixon RA, Mathews PM, Cataldo AM. The neuronal endosomal-lysosomal system in Alzheimer's disease. J Alzheimers Dis. 2001; 3:97-107.

6. Maciejewski R, Burski K, Baj J, Madej B, Burdan F, Dabrowski A, Brakowiecki F. Changes in pancreatic lysosomal enzymes activity as the potential factors leading to diabetic enteropathy. J Physiol Pharmacol. 2001; 52:823834.

7. Tiribuzi R, Orlacchio A, Crispoltoni L, Maiotti M, Zampolini M, De Angeliz M, Mecocci P, Cecchetti R, Bernardi G, Datti A, Martino S, Orlacchio A. Lysosomal $\beta$-galactosidase and $\beta$-hexosaminidase activities correlate with clinical stages of dementia associated with Alzheimer's disease and type 2 diabetes mellitus. J Alzheimers Dis. 2011; 24:785-97.

8. Emiliani C, Urbanelli L, Racanicchi L, Orlacchio A, Pelicci G, Sorbi S, Bernardi G, Orlacchio A. Up-regulation of glycohydrolases in Alzheimer's Disease fibroblasts correlates with Ras activation. J Biol Chem. 2003; 278:38453-60.

9. Kalanj-Bognar S, Rundek T, Furac I, Demarin V, Cosović C. Leukocyte lysosomal enzymes in Alzheimer's disease and Down's syndrome. J Gerontol A Biol Sci Med Sci. 2002; 57:B16-21.

10. Magini A, Polchi A, Tozzi A, Tancini B, Tantucci M, Urbanelli L, Borsello T, Calabresi P, Emiliani C. Abnormal cortical lysosomal $\beta$-hexosaminidase and $\beta$-galactosidase activity at post-synaptic sites during Alzheimer's disease progression. Int J Biochem Cell Biol. 2015; 58:62-70.

11. Horvath S, Garagnani P, Bacalini MG, Pirazzini C, Salvioli S, Gentilini D, Di Blasio AM, Giuliani C, Tung S, Vinters $\mathrm{HV}$, Franceschi C. Accelerated epigenetic aging in Down syndrome. Aging Cell. 2015; 14:491-5.

12. Magini A, Polchi A, Tancini B, Urbanelli L, Hasilik A, Emiliani C. Glycohydrolases $\beta$-hexosaminidase and $\beta$-galactosidase are associated with lipid microdomains of Jurkat T-lymphocytes. Biochimie. 2012; 94:684-94.

13. Holt OJ, Gallo F, Griffiths GM. Regulating secretory lysosomes. J Biochem. 2006; 140:7-12.

14. Takenouchi T, Nakai M, Iwamaru Y, Sugama S, Tsukimoto M, Fujita M, Wei J, Sekigawa A, Sato M, Kojima S, Kitani H, Hashimoto M. The activation of P2X7 receptor impairs lysosomal functions and stimulates the release of autophagolysosomes in microglial cells. J Immunol. 2009; 182:2051-62.

15. Ponpuak M, Mandell MA, Kimura T, Chauhan S, Cleyrat C, Deretic V. Secretory autophagy. Curr Opin Cell Biol. 2015; 35:106-16.

16. Dimri GP, Lee X, Basile G, Acosta M, Scott G, Roskelley C, Medrano EE, Linskens M, Rubelj I, Pereira-Smith O. A biomarker that identifies senescent human cells in culture and in aging skin in vivo. Proc Natl Acad Sci USA. 1995; 92:9363-67.
17. Lee BY, Han JA, Im JS, Morrone A, Johung K, Goodwin EC, Kleijer WJ, DiMaio D, Hwang ES. Senescenceassociated beta-galactosidase is lysosomal betagalactosidase. Aging Cell. 2006; 5:187-95.

18. Itahana K, Campisi J, Dimri GP. Methods to detect biomarkers of cellular senescence: the senescenceassociated beta-galactosidase assay. Methods Mol Biol. 2007; 371:21-31.

19. Sikora E, Bielak-Zmijewska A, Mosieniak G. Cellular senescence in ageing, age-related disease and longevity. Curr Vasc Pharmacol. 2014; 12:698-706.

20. Maier AB, Westendorp RG, VAN Heemst D. Betagalactosidase activity as a biomarker of replicative senescence during the course of human fibroblast cultures. Ann N Y Acad Sci. 2007; 1100:323-32.

21. Olivieri F, Albertini MC, Orciani M, Ceka A, Cricca M, Procopio AD, Bonafè M. DNA damage response (DDR) and senescence: shuttled inflamma-miRNAs on the stage of inflamm-aging. Oncotarget. 2015; 6:35509-21. https://doi. org/10.18632/oncotarget.5899.

22. Childs BG, Durik M, Baker DJ, van Deursen JM. Cellular senescence in aging and age-related disease: from mechanisms to therapy. Nat Med. 2015; 21:1424-35.

23. Dariusz Szajda S, Waszkiewicz N, Stypułkowska A, Dadan J, Zwierz K. Lysosomal exoglycosidases in serum and urine of patients with pancreatic adenocarcinoma. Folia Histochem Cytobiol. 2010; 48:351-7.

24. Szajda SD, Snarska J, Puchalski Z, Zwierz K. Lysosomal exoglycosidases in serum and urine of patients with colon adenocarcinoma. Hepatogastroenterology. 2008; 55:921-5.

25. Wasiluk A, Waszkiewicz N, Szajda SD, WojewódzkaŻelezniakowicz M, Kępka A, Minarowska A, Zwierz ZW, Pancewicz S, Ładny JR, Zwierz K. Alpha fucosidase and beta galactosidase in serum of a Lyme disease patients as a possible marker of accelerated senescence - a preliminary study. Folia Histochem Cytobiol. 2012; 50:270-4.

26. Vanhooren V, Dewaele S, Libert C, Engelborghs S, De Deyn PP, Toussaint O, Debacq-Chainiaux F, Poulain M, Glupczynski Y, Franceschi C, Jaspers K, van der Pluijm I, Hoeijmakers J, et al. Serum N-glycan profile shift during human ageing. Exp Gerontol. 2010; 45:738-43.

27. Dall'Olio F, Vanhooren V, Chen CC, Slagboom PE, Wuhrer M, Franceschi C. N-glycomic biomarkers of biological aging and longevity: a link with inflammaging. Ageing Res Rev. 2013; 12:685-98.

28. Testa R, Vanhooren V, Bonfigli AR, Boemi M, Olivieri F, Ceriello A, Genovese S, Spazzafumo L, Borelli V, Bacalini MG, Salvioli S, Garagnani P, Dewaele S, et al. N-glycomic changes in serum proteins in type 2 diabetes mellitus correlate with complications and with metabolic syndrome parameters. PLoS One. 2015; 10:e119983.

29. Orimo H, Ito H, Suzuki T, Araki A, Hosoi T, Sawabe M. Reviewing the definition of "elderly". Geriatr Gerontol Int. 2006; 6:149-58. 
30. Singh S, Bajorek B. Defining 'elderly' in clinical practice guidelines for pharmacotherapy. Pharm Pract (Granada). 2014; $12: 489$.

31. Kirkland JL, Tchkonia T. Cellular Senescence: A Translational Perspective. EBioMedicine. 2017; 21:21-28.

32. Palmer AK, Tchkonia T, LeBrasseur NK, Chini EN, Xu M, Kirkland JL. Cellular Senescence in Type 2 Diabetes: A Therapeutic Opportunity. Diabetes. 2015; 64:2289-98.

33. Prattichizzo F, De Nigris V, La Sala L, Procopio AD, Olivieri F, Ceriello A. "Inflammaging" as a Druggable Target: A Senescence-Associated Secretory PhenotypeCentered View of Type 2 Diabetes. Oxid Med Cell Longev. 2016; $2016: 1810327$.

34. Spazzafumo L, Olivieri F, Abbatecola AM, Castellani G, Monti D, Lisa R, Galeazzi R, Sirolla C, Testa R, Ostan R, Scurti M, Caruso C, Vasto S, et al. Remodelling of biological parameters during human ageing: evidence for complex regulation in longevity and in type 2 diabetes. Age (Dordr). 2013; 35:419-29.

35. Zummo FP, Cullen KS, Honkanen-Scott M, Shaw JA, Lovat PE, Arden C. Glucagon-like Peptide-1 Protects Pancreatic Beta-cells from Death by Increasing Autophagic Flux and Restoring Lysosomal Function. Diabetes. 2017; 66:12721285.

36. Serrano MA, Cabezas JA, Reglero A. Carbohydrate contents, and glycosidase and glycosyl transferase activities in tissues from streptozotocin diabetic mice. Comp Biochem Physiol B. 1985; 80:629-32.

37. Suh MJ, Tovchigrechko A, Thovarai V, Rolfe MA, Torralba MG, Wang J, Adkins JN, Webb-Robertson BJ, Osborne W, Cogen FR, Kaplowitz PB, Metz TO, Nelson KE, et al. Quantitative Differences in the Urinary Proteome of Siblings Discordant for Type 1 Diabetes Include Lysosomal Enzymes. J Proteome Res. 2015; 14:3123-35.

38. Olivieri F, Lazzarini R, Recchioni R, Marcheselli F, Rippo MR, Di Nuzzo S, Albertini MC, Graciotti L, Babini L, Mariotti S, Spada G, Abbatecola AM, Antonicelli $\mathrm{R}$, et al. MiR-146a as marker of senescence-associated pro-inflammatory status in cells involved in vascular remodelling. Age (Dordr). 2013; 35:1157-72.

39. Yang WH, Aziz PV, Heithoff DM, Mahan MJ, Smith JW, Marth JD. An intrinsic mechanism of secreted protein aging and turnover. Proc Natl Acad Sci U S A. 2015; 112:1365762.
40. Leunissen EH, Blanchard MG, Sheedfar F, Lavrijsen M, van der Wijst J, Bindels RJ, Hoenderop JG. Urinary $\beta$-galactosidase stimulates $\mathrm{Ca} 2+$ transport by stabilizing TRPV5 at the plasma membrane. Glycobiology. 2016; 26:472-81.

41. Krištić J, Vučković F, Menni C, Klarić L, Keser T, Beceheli I, Pučić-Baković M, Novokmet M, Mangino M, Thaqi K, Rudan P, Novokmet N, Sarac J, et al. Glycans are a novel biomarker of chronological and biological ages. J Gerontol A Biol Sci Med Sci. 2014; 69:779-89.

42. Jylhävä J, Pedersen NL, Hägg S. Biological Age Predictors. EBioMedicine. 2017; 21:29-36.

43. Karsten CM, Pandey MK, Figge J, Kilchenstein R, Taylor PR, Rosas M, McDonald JU, Orr SJ, Berger M, Petzold D, Blanchard V, Winkler A, Hess C, et al. Anti-inflammatory activity of IgG1 mediated by $\mathrm{Fc}$ galactosylation and association of Fc $\gamma$ RIIB and dectin-1. Nat Med. 2012; 18:1401-6.

44. Catera M, Borelli V, Malagolini N, Chiricolo M, Venturi G, Reis CA, Osorio H, Abruzzo PM, Capri M, Monti D, Ostan R, Franceschi C, Dall'Olio F. Identification of novel plasma glycosylation-associated markers of aging. Oncotarget. 2016; 7:7455-68. https://doi.org/10.18632/oncotarget.7059.

45. Franceschi C, Bonafè M, Valensin S, Olivieri F, De Luca M, Ottaviani E, De Benedictis G. Inflamm-aging. An evolutionary perspective on immunosenescence. Ann N Y Acad Sci. 2000; 908:244-54.

46. Testa R, Olivieri F, Sirolla C, Spazzafumo L, Rippo MR, Marra M, Bonfigli AR, Ceriello A, Antonicelli R, Franceschi C, Castellucci C, Testa I, Procopio AD. Leukocyte telomere length is associated with complications of type 2 diabetes mellitus. Diabet Med. 2011; 28:1388-94.

47. Haendeler J, Hoffmann J, Diehl JF, Vasa M, Spyridopoulos I, Zeiher AM, Dimmeler S. Antioxidants inhibit nuclear export of telomerase reverse transcriptase and delay replicative senescence of endothelial cells. Circ Res. 2004; 94:768-75.

48. Bradford MM. A rapid and sensitive method for the quantitation of microgram quantities of protein utilizing the principle of protein-dye binding. Anal Biochem. 1976; $72: 248-54$.

49. Coppa GV, Maiorana A, Gabrielli O, Sani S. Glycosaminoglycans from urine and tissues in mucolipidosis II (I-cell disease). Clin Chim Acta. 1979; 95:135-7. 